\title{
Vibrio crassostreae sp. nov., isolated from the haemolymph of oysters (Crassostrea gigas)
}

Correspondence
F. Le Roux
fleroux@ifremer.fr

\author{
N. Faury, ${ }^{1}$ D. Saulnier, ${ }^{1}$ F. L. Thompson, ${ }^{2}$ M. Gay, ${ }^{1}$ J. Swings ${ }^{2}$ \\ and F. Le Roux ${ }^{1}$ \\ ${ }^{1}$ Laboratoire de Génétique et Pathologie, Institut français de recherche pour l'exploitation \\ de la mer (Ifremer), 17390 La Tremblade, France \\ ${ }^{2}$ Laboratory for Microbiology and BCCM ${ }^{\mathrm{TM}} / \mathrm{LMG}$ Bacteria Collection, Laboratory for \\ Microbiology, Ghent University, K.L. Ledeganckstraat 35, Ghent 9000, Belgium
}

\begin{abstract}
Polyphasic analysis of five new Vibrio isolates originating from the haemolymph of diseased cultured oysters is described. The new isolates were closely related to Vibrio splendidus, having $98 \% 16 \mathrm{~S}$ rRNA gene sequence similarity. gyrB phylogenetic analysis, fluorescent amplified-fragment length polymorphism (FAFLP) fingerprinting and DNA-DNA hybridization experiments clearly showed that the new isolates form a tight genomic group that is different from the currently known Vibrio species. It is proposed to accommodate these isolates in a novel species, Vibrio crassostreae sp. nov. (type strain LGP $7^{\top}=\mathrm{LMG} 22240^{\top}=$ CIP $108327^{\top}$ ). Phenotypic and chemotaxonomic features that differentiate $V$. crassostreae from other known Vibrio species include arginine dihydrolase, utilization and fermentation of various carbon sources, $\beta$-galactosidase activity, $\mathrm{NO}_{2}$ production and the presence of the fatty acids $14: 0$ iso and $16: 0$ iso.
\end{abstract}

Vibrio splendidus-related species have been associated with mortality of molluscs and fish (Nicolas et al., 1996; Sugumar et al., 1998; Gatesoupe et al., 1999; Lacoste et al., 2001; Waechter et al., 2002; Farto et al., 2003). Epidemiological studies of $V$. splendidus strains associated with oyster mortality outbreaks have demonstrated a high genetic diversity within this group and suggested its polyphyletic nature (Le Roux et al., 2002, 2004). Six species, Vibrio lentus, Vibrio kanaloae, Vibrio pomeroyi, Vibrio tasmaniensis, Vibrio chagasii and V. splendidus, have been described within this group so far, but there exist only a limited number of diagnostic biochemical features that allow clear species discrimination within this group (Macián et al., 2001; Thompson et al., 2003a, b). In a previous study we investigated a collection of $V$. splendidus-related isolates originated from the haemolymph of oysters that are potentially pathogenic for the oyster Crassostrea gigas (Gay et al., 2004). These strains were characterized by DNA gyrase subunit B $(\operatorname{gyr} B)$ gene sequencing (Le Roux

Published online ahead of print on 21 May 2004 as DOI 10.1099/ ijs.0.63232-0.

Abbreviation: FAFLP, fluorescent amplified-fragment length polymorphism.

The GenBank/EMBL/DDBJ accession numbers for the 16S rRNA and gyrB gene sequences of LGP $7^{\top}$ are AJ582808 and AJ582799, respectively.

Tables of supplementary DNA-DNA hybridization, phenotypic and fatty acid data are available in IJSEM Online. et al., 2004). Several strains clustered together but could not be assigned to any known Vibrio species. In the present study we present a detailed polyphasic analysis of a group of five Vibrio isolates, including $16 \mathrm{~S}$ rRNA and gyrB gene sequencing, fluorescent amplified-fragment length polymorphism (FAFLP) fingerprinting, DNA-DNA hybridizations and biochemical tests. Collectively, the results suggest that the five isolates belong to a novel species, for which we propose the name Vibrio crassostreae sp. nov.

The strains used in this study were purchased from national collections ( $V$. splendidus LMG $4042^{\mathrm{T}}$, V. tasmaniensis LMG $20012^{\mathrm{T}}$, V. kanaloae LMG 20539 ${ }^{\mathrm{T}}$, V. pomeroyi LMG $20537^{\mathrm{T}}$, Vibrio cyclitrophicus LMG $21359^{\mathrm{T}}$, V. chagasii LMG $21353^{\mathrm{T}}$, $V$. lentus CIP $107166^{\mathrm{T}}$ ) or isolated from the haemolymph of cultured C. gigas in La Tremblade (France) [LMG $22240^{\mathrm{T}}$ $\left(=\mathrm{LGP} 7^{\mathrm{T}}=\right.$ CIP $\left.108327^{\mathrm{T}}\right)$, LMG 22241 (=LGP $8=$ CIP 108328), LMG 22248 (=LGP $15=$ CIP 108329), LMG 22249 ( = LGP $107=$ CIP 108330), LMG 22242 (=LGP 17), LMG 22243 (=LGP 1) and LGP 108)] and deposited in the BCCM/LMG Bacteria Collection (Gent, Belgium) and in the Institut Pasteur Bacteria Collection (CIP; Paris, France). All strains were cultured on tryptone soy agar (TSA; Oxoid) supplemented with $2 \%(\mathrm{w} / \mathrm{v}) \mathrm{NaCl}$ for $48 \mathrm{~h}$ at $20^{\circ} \mathrm{C}$.

PCR amplification, cloning and sequencing of the $16 \mathrm{~S}$ rRNA and $g y r B$ gene fragments were done as described previously (Yamamoto \& Harayama, 1995; Lambert et al., 1998; Le Roux et al., 2004). Sequences were aligned and phylogenetic analyses were performed with SEAVIEW and 
PHYLO_WIN software (Galtier et al., 1996). Phylogenetic trees were constructed using neighbour-joining, maximumlikelihood and maximum-parsimony. For neighbourjoining analysis, distance matrices were calculated by using Kimura's 2-parameter distances (Gascuel, 1997). Reliability of topologies was assessed by the bootstrap method with 1000 replicates. FAFLP analysis was carried out as described previously (Thompson et al., 2001).

For DNA-DNA hybridization experiments, in vitro labelling of the DNA with tritium-labelled nucleotides was performed by the random primer method (Megaprime labelling kit; Amersham) and hybridization was carried out at $60{ }^{\circ} \mathrm{C}$ by the S1-nuclease method (Crosa et al., 1973; Grimont et al., 1980) with adsorption of S1-resistant DNA onto Whatman DE81 filters.

Phenotypic characterization of the strains was done using the following commercially available kits: the Gram kit (bioMérieux), oxidase (Bactident oxidase; Merck), respiratory activity (meat liver medium; Diagnostic Pasteur), glucose metabolism (MEVAG; Diagnostic Pasteur), API 20E and API 50CH (bioMérieux) with the modification suggested by MacDonell et al. (1982), namely $2 \% \mathrm{NaCl}$ was added to the bacterial suspension. Motility, $\mathrm{NaCl}$ requirement and tolerance $(0,2,4,6,8$ and $10 \%, w / v)$ and temperature tolerance $\left(4,20,35\right.$ and $\left.40{ }^{\circ} \mathrm{C}\right)$ were tested in $1.5 \%(\mathrm{w} / \mathrm{v})$ peptone broth (Diagnostic Pasteur). Numerical analysis of phenotypic features was performed using simple matching coefficients (Sneath, 1972) and the unweighted pair group method (Sneath \& Sokal, 1973). Sensitivity to $\mathrm{O} / 129$ (150 $\mu \mathrm{g}$ per disc) was determined with Oxoid discs. Fatty acid methyl ester analysis was carried out as described by Huys et al. (1994).

The phylogenetic tree based on the gyrB nucleotide sequences (1064 gap-free sites long) confirmed the clustering of $V$. crassostreae sp. nov. strains LGP $7^{\mathrm{T}}$, LGP 8, LGP 15, LGP 107 and LGP 108 with a bootstrap value of $100 \%$ and their distinction from their closest phylogenetic neighbours $V$. cyclitrophicus, $V$. lentus, $V$. pomeroyi, $V$. kanaloae, $V$. tasmaniensis and $V$. splendidus (Fig. 1). The phylogenetic tree based on almost-complete sequences of the $16 \mathrm{~S}$ rRNA gene does not allow clear differentiation of the two representative isolates (LGP $7^{\mathrm{T}}$ and LGP 8) from other species phenotypically related to $V$. splendidus (Fig. 2). Results are in accordance with previous studies, showing that the $16 \mathrm{~S}$ rRNA gene sequences of $V$. splendidus-related strains are very similar (Macián et al., 2001; Le Roux et al., 2002, 2004; Thompson et al., 2003a, b). Similar results were obtained by maximum-parsimony and maximum-likelihood analyses (data not shown).

The FAFLP patterns of four representative $V$. crassostreae strains consisted of 125 bands ( $\pm 9 \mathrm{SD}$ ). The mutual FAFLP pattern similarity among these strains was at least $86 \%$. Strains of $V$. crassostreae sp. nov. were clearly differentiated from all the other currently known species of the Vibrionaceae, V. splendidus and V. kanaloae being the most closely

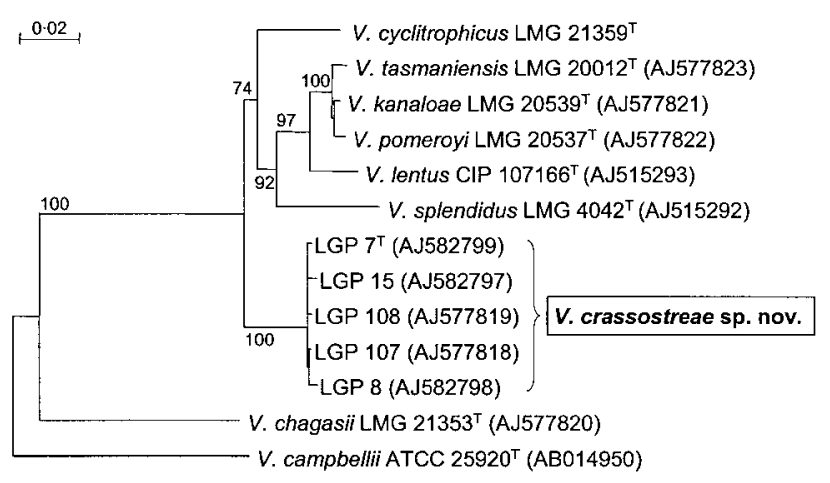

Fig. 1. Phylogenetic tree of partial gyrB sequences. The Vibrio campbellii homologue was used as the outgroup; 1064 gapfree sites were compared. Horizontal branch lengths are proportional to evolutionary divergence. Bootstrap percentages from 1000 replicates appear next to the corresponding branch.

related, with $54 \%$ similarity (Fig. 3). The FAFLP data suggest that the isolates indeed belong to a novel Vibrio species.

DNA-DNA hybridization experiments confirmed the grouping found with FAFLP and gyrB. $V$. crassostreae strains had at least $78 \%$ DNA-DNA relatedness, but at maximum $61 \%$ towards five other $V$. splendidus-related species (Supplementary Table A in IJSEM Online).

Strains of $V$. crassostreae sp. nov. could be differentiated from their closest phylogenetic neighbours by 17 phenotypic characters analysed in this study (Supplementary Table B). Those tests were coded as 1 (positive result) or 0 (negative result) and numerical analysis was performed using simple matching coefficients (Fig. 4). V. crassostreae sp. nov. has the main fatty acid traits of vibrios, i.e. $16: 1 \omega 7 c$ and/or $15: 0$ iso $2-\mathrm{OH}, 18: 1 \omega 7 c, 12: 0,14: 0,12: 03-\mathrm{OH}$ (Supplementary Table C). The fatty acids 16:0 iso and

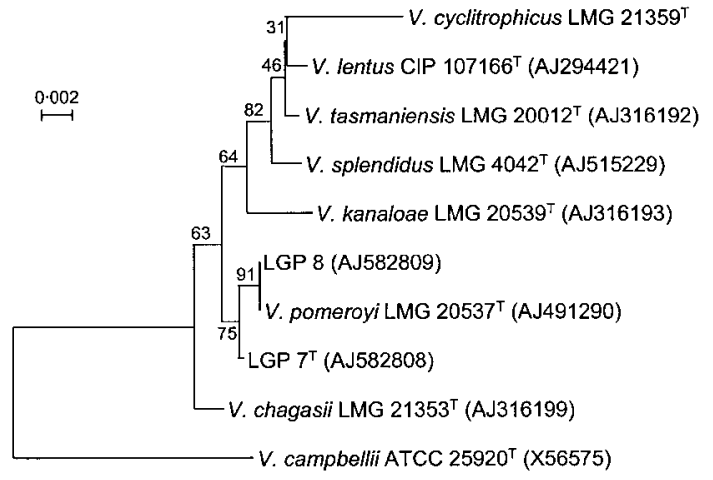

Fig. 2. Phylogenetic tree of partial $16 \mathrm{~S}$ rRNA gene sequences; 1200 gap-free sites were compared. Other features as in Fig. 1. 


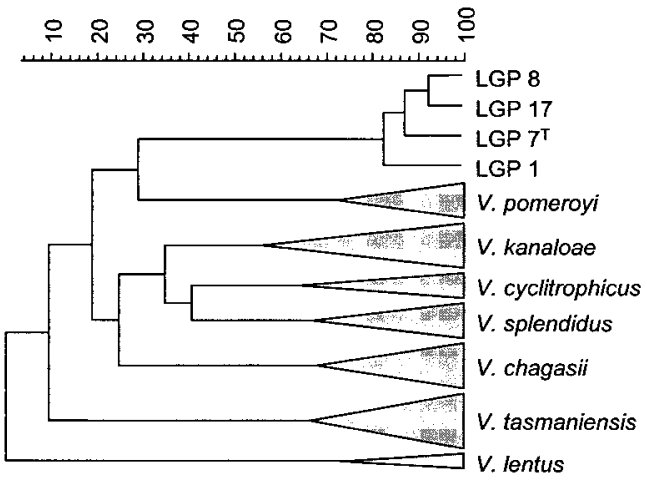

Fig. 3. Dendrogram (Dice, Ward) of the FAFLP band patterns of $V$. crassostreae sp. nov. and all other known $V$. splendidusrelated species.

14:0 iso seem to be useful for discriminating among $V$. splendidus-related species.

The present study illustrates the use of the gyrB-based phylogenetic structure in an interim period to cluster strains before validation of species affiliation by DNADNA hybridization and description of phenotypic features. However, in the case of $V$. pomeroyi, $V$. kanaloae and $V$. tasmaniensis, our gyrB-based analysis appears to be less discriminatory than DNA-DNA hybridization or FAFLP fingerprinting (Thompson et al., 2001). Sequence analyses of other loci, including rpoD (Yamamoto \& Harayama, 1998) and hsp60 sequences (Kwok et al., 2002), are in progress in order to assess the usefulness of such genes to discriminate $V$. splendidus-related species.

\section{Description of Vibrio crassostreae sp. nov.}

Vibrio crassostreae (cra.sso.stre' ae. N.L. gen. n. crassostreae of Crassostrea gigas, the oyster species from which the strains were isolated).

Cells are Gram-negative, curved, $1 \mu \mathrm{m}$ wide and $2-3 \mu \mathrm{m}$

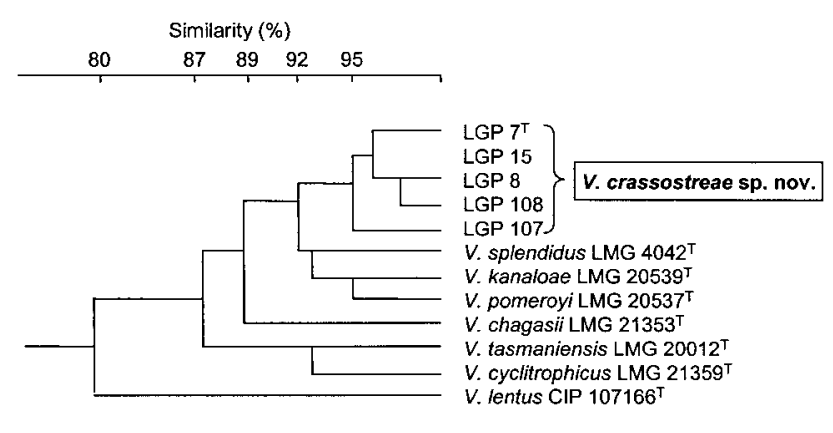

Fig. 4. Cluster analysis of phenetic data for Vibrio species using simple matching-similarity coefficient and unweighted pair group method (expressed as a percentage on the scale bar) for 12 strains related to $V$. splendidus. long. Cells are motile by at least one polar flagellum. Forms translucent, non-swarming, rounded colonies with entire margins on TSA. Strains form yellow, translucent, $5 \mathrm{~mm}$ colonies on thiosulfate-citrate-bile salts-sucrose (TCBS) agar. Cells grow at $4{ }^{\circ} \mathrm{C}$. None of the strains grows at 0 or $8 \% \mathrm{NaCl}$. All strains are $\beta$-galactosidase-negative, arginine dihydrolase- and gelatinase-positive. Oxidase- and catalasepositive and urease-negative. Facultatively anaerobic and produces $\mathrm{NO}_{2}$. The following compounds are utilized as sole carbon sources: glucose, sucrose, melibiose, amygdalin, glycerol, ribose, galactose, D-mannose, mannitol, $\mathrm{N}$-acetylglucosamine, aesculin, cellobiose, starch, glycogen and L-fucose. None of the strains utilize inositol, rhamnose, arabinose, erythritol, D- or L-arabinose, D- or L-xylose, adonitol, methyl $\beta$-D-xyloside, L-sorbose, dulcitol, sorbitol, methyl $\alpha$-D-mannoside, methyl $\alpha$-D-glucoside, amygdalin, arbutin, salicin, lactose, inulin, melezitose, D-raffinose, xylitol, $\beta$-gentiobiose, $\mathrm{D}$-turanose, D-lyxose, D-tagatose, Dfucose, D- or L-arabitol, 2-oxoglutarate or 5-oxoglutarate. All strains are sensitive to $\mathrm{O} / 129$. Major fatty acids are summed feature $3(39 \cdot 4 \pm 1 \%$, comprising $16: 1 \omega 7 c$ and/or $15: 0$ iso $2-\mathrm{OH}), 16: 0(17 \cdot 3 \pm 1 \cdot 3 \%), 16: 0$ iso $(8 \cdot 7 \pm 0 \cdot 2 \%), \quad 18: 1 \omega 7 c(7 \pm 1 \cdot 3 \%), \quad 12: 0 \quad(5 \cdot 5 \pm 0 \cdot 3 \%)$, $14: 0 \quad(5 \cdot 4 \pm 1 \%), \quad 12: 0 \quad 3-\mathrm{OH} \quad(3 \cdot 3 \pm 0 \cdot 2 \%)$, summed feature $2(2 \cdot 6 \pm 0 \cdot 1 \%$, comprising $14: 03-\mathrm{OH}$ and/or $16: 1$ iso I and/or unidentified fatty acid with equivalent chain-length value of 10.928 and/or 12:0 ALDE), 14:0 iso $(1 \cdot 6 \%), 17: 0(1.4 \%), 17: 1 \omega 8 c(1.3 \%)$ and $14: 0$ iso $3-\mathrm{OH}(1 \cdot 2 \%)$.

Type strain LGP $7^{\mathrm{T}}\left(=\mathrm{LMG} 22240^{\mathrm{T}}=\mathrm{CIP} 108327^{\mathrm{T}}\right)$ was isolated from a diseased oyster (Crassostrea gigas) at the laboratoire de genetique et pathologie (Ifremer, France). Reference strains are LMG 22241 ( = LGP $8=$ CIP 108328), LMG 22248 ( = LGP $15=$ CIP 108329), LMG 22249 (=LGP $107=\mathrm{CIP} 108330)$ and LGP 108. The GenBank/EMBL/ DDBJ accession numbers for the $16 \mathrm{~S}$ and $\operatorname{gyr} B$ gene sequences of LGP $7^{\mathrm{T}}$ are AJ582808 and AJ582799, respectively.

\section{Acknowledgements}

This study was carried out with financial assistance from the French Research and Technological Ministry (CRB: Collection de Ressources Biologique) and the European Community Reference Laboratory for Bivalve Mollusc Diseases. F. L. T. acknowledges a postdoctoral grant from the BCCM ${ }^{\mathrm{TM}} / \mathrm{LMG}$ Bacteria Collection, Belgium. J. S. acknowledges grants from the Fund for Scientific Research (FWO), Belgium.

\section{References}

Crosa, J. H., Brenner, D. J. \& Falkow, S. (1973). Use of a singlestrand specific nuclease for analysis of bacterial and plasmid deoxyribonucleic acid homo- and heteroduplexes. J Bacteriol 115, 904-911.

Farto, R., Armada, S. P., Montes, M., Guisande, J. A., Perez, M. J. \& Nieto, T. P. (2003). Vibrio lentus associated with diseased wild octopus (Octopus vulgaris). J Invertebr Pathol 83, 149-156. 
Galtier, N., Gouy, M. \& Gautier, C. (1996). SEAVIEW and PHYLO_WIN: two graphic tools for sequence alignment and molecular phylogeny. Comput Appl Biosci 12, 543-548.

Gascuel, O. (1997). BIONJ: an improved version of the NJ algorithm based on a simple model of sequence data. Mol Biol Evol 14, 685-695.

Gatesoupe, F. J., Lambert, C. \& Nicolas, J. L. (1999). Pathogenicity of Vibrio splendidus strains associated with turbot larvae, Scophthalmus maximus. J Appl Microbiol 87, 757-763.

Gay, M., Berthe, F. C. J. \& Le Roux, F. (2004). Screening of Vibrio isolates to develop an experimental infection model in the Pacific oyster Crassostrea gigas. Dis Aquat Organ 59, 49-56.

Grimont, P. A. D., Popoff, M. Y., Grimont, F., Coynault, C. \& Lemelin, M. (1980). Reproducibility and correlation study of three deoxyribonucleic acid hybridisation procedures. Curr Microbiol 4, 325-330.

Huys, G., Vancanneyt, M., Coopman, R., Janssen, P., Falsen, E., Altwegg, M. \& Kersters, K. (1994). Cellular fatty acid composition as a chemotaxonomic marker for the differentiation of phenospecies and hybridization groups in the genus Aeromonas. Int J Syst Bacteriol 44, 651-658.

Kwok, A. Y., Wilson, J. T., Coulthart, M., Ng, L. K., Mutharia, L. \& Chow, A. W. (2002). Phylogenetic study and identification of human pathogenic Vibrio species based on partial hsp60 gene sequences. Can J Microbiol 48, 903-910.

Lacoste, A., Jalabert, F., Malham, S., Cueff, A., Gélébart, F., Cordevant, C., Lange, M. \& Poulet, S. A. (2001). A Vibrio splendidus strain is associated with summer mortality of juvenile oysters Crassostrea gigas in the Bay of Morlaix (North Brittany, France). Dis Aquat Organ 46, 139-145.

Lambert, C., Nicolas, J. L., Cilia, V. \& Corre, S. (1998). Vibrio pectenicida sp. nov., a pathogen of scallop (Pecten maximus) larvae. Int J Syst Bacteriol 48, 481-487.

Le Roux, F., Gay, M., Lambert, C., Waechter, M., Poubalanne, S., Chollet, B., Nicolas, J. L. \& Berthe, F. C. J. (2002). Comparative analysis of Vibrio splendidus-related strains isolated during Crassostrea gigas mortality events. Aquat Living Resour 15, 251-258.

Le Roux, F., Gay, M., Lambert, C., Nicolas, J. L., Gouy, M. \& Berthe, F. C. J. (2004). Phylogenetic study and identification of Vibrio splendidus-related strains based on gyrB gene sequences. Dis Aquat Organ 58, 143-150.
MacDonell, M. T., Singleton, F. L. \& Hood, M. A. (1982). Diluent composition for use of API $20 \mathrm{E}$ in characterizing marine and estuarine bacteria. Appl Environ Microbiol 44, 423-427.

Macián, M. C., Ludwig, W., Aznar, R., Grimont, P. A. D., Schleifer, K. H., Garay, E. \& Pujalte, M. J. (2001). Vibrio lentus sp. nov., isolated from Mediterranean oysters. Int J Syst Evol Microbiol 51, 1449-1456.

Nicolas, J. L., Corre, S., Gauthier, G., Robert, R. \& Ansquer, D. (1996). Bacterial problems associated with scallop Pecten maximus larval culture. Dis Aquat Organ 27, 67-76.

Sneath, P. H. A. (1972). Computer taxonomy. Methods Microbiol 7, 29-98.

Sneath, P. H. A. \& Sokal, R. R. (1973). Numerical Taxonomy: the Principles and Practice of Numerical Classification. San Francisco: W. H. Freeman.

Sugumar, G., Nakai, T., Hirata, Y., Matsubara, D. \& Muroga, K. (1998). Vibrio splendidus biovar II as the causative agent of bacillary necrosis of Japanese oyster Crassostrea gigas larvae. Dis Aquat Organ 33, 111-118.

Thompson, F. L., Hoste, B., Vandemeulebroecke, K. \& Swings, J. (2001). Genomic diversity amongst Vibrio isolates from different sources determined by fluorescent amplified fragment length polymorphism. Syst Appl Microbiol 24, 520-538.

Thompson, F. L., Thompson, C. C., Li, Y., Gomez-Gil, B., Vandenberghe, J., Hoste, B. \& Swings, J. (2003a). Vibrio kanaloae sp. nov., Vibrio pomeroyi sp. nov. and Vibrio chagasii sp. nov., from sea water and marine animals. Int J Syst Evol Microbiol 53, 753-759.

Thompson, F. L., Thompson, C. C. \& Swings, J. (2003b). Vibrio tasmaniensis sp. nov., isolated from Atlantic salmon (Salmo salar L.). Syst Appl Microbiol 26, 65-69.

Waechter, M., Le Roux, F., Nicolas, J. L., Marissal, E. \& Berthe, F. (2002). Characterization of pathogenic bacteria of the cupped oyster Crassostrea gigas. C R Biol 325, 231-238 (in French).

Yamamoto, S. \& Harayama, S. (1995). PCR amplification and direct sequencing of gyrB genes with universal primers and their application to the detection and taxonomic analysis of Pseudomonas putida strains. Appl Environ Microbiol 61, 1104-1109.

Yamamoto, S. \& Harayama, S. (1998). Phylogenetic relationships of Pseudomonas putida strains deduced from the nucleotide sequences of gyrB, rpoD and $16 \mathrm{~S}$ rRNA genes. Int J Syst Bacteriol 48, 813-819. 